\title{
New record and cytogenetic analysis of Psammolestes tertius Lent \& Jurberg, 1965 (Hemiptera, Reduviidae, Triatominae) from Bahia State, Brazil
}

\author{
J. Oliveira ${ }^{1}$, K.C.C. Alevi ${ }^{2}$, E.O.L. Fonseca ${ }^{3}$, O.M.F. Souza ${ }^{3}$, \\ C.G.S. Santos ${ }^{3}$, M.T.V. Azeredo-Oliveira ${ }^{2}$ and J.A. da Rosa ${ }^{1}$ \\ ${ }^{1}$ Laboratório de Parasitologia, Departamento de Ciências Biológicas, \\ Faculdade de Ciências Farmacêuticas, \\ Universidade Estadual Paulista "Júlio de Mesquita Filho", Araraquara, SP, Brasil \\ ${ }^{2}$ Laboratório de Biologia Celular, Departamento de Biologia, \\ Instituto de Biociências, Letras e Ciências Exatas, \\ Universidade Estadual Paulista "Júlio de Mesquita Filho", \\ São José do Rio Preto, SP, Brasil \\ ${ }^{3}$ Laboratório Central de Saúde Pública Professor Gonçalo Moniz, Candeal, \\ Salvador, BA, Brasil \\ Corresponding author: K.C.C. Alevi \\ E-mail: kaiochaboli@hotmail.com
}

Genet. Mol. Res. 15 (2): gmr.15028004

Received November 5, 2015

Accepted December 23, 2015

Published June 21, 2016

DOI http://dx.doi.org/10.4238/gmr.15028004

ABSTRACT. This paper reports on the first occurrence of Psammolestes tertius in the Chapada Diamantina region, located in the city of Seabra, Bahia State, in northeastern Brazil. Following an active search, $24 P$. tertius specimens were collected from Phacellodomus rufifrons (rufousfronted thornbird) nests. The insects did not present any symptoms of infection by Trypanosoma cruzi. P. tertius males were cytogenetically analyzed, and the results were compared with those of other specimens from the Brazilian State of Ceará. Triatomines from both locations 
presented the same cytogenetic characteristics: 22 chromosomes, little variation in the size of the autosomes, $\mathrm{Y}$ chromosomes that were larger than the $\mathrm{X}$ chromosomes, a chromocenter formed only by the sex chromosomes during prophase, and autosomes lacking constitutive heterochromatin. However, it is important to note that this species shows intraspecific chromosomal variation. In light of the results obtained, it is recommended that more studies be performed to characterize $P$. tertius. These studies will be particularly helpful in understanding this species in ecological, biological, biogeographical, and phylogenetic terms.

Key words: Triatominae subfamily; Chapada Diamantina; Chromosomal variation

\section{INTRODUCTION}

The Triatominae subfamily is composed of 151 species grouped into 18 genera (Alevi et al., 2015a; Mendonça et al., 2016). All triatomine species are bloodsucking bugs and are potential vectors of the protozoan Trypanosoma cruzi Chagas, 1909, an etiological agent of Chagas disease.

In Brazil, 65 triatomine species have been reported. They are distributed into ten genera: Alberprosenia Martínez and Carcavallo, 1977; Belminus Stål, 1859; Cavernicola Barber, 1937; Eratyrus Stål, 1859; Microtriatoma (Lent, 1951); Panstrongylus Berg, 1879; Parabelminus Lent, 1943; Psammolestes Bergroth, 1911; Rhodnius Stål, 1859; and Triatoma Laporte, 1832. With 23 species, the Brazilian State of Bahia has the greatest species diversity to date. It is believed that one of the reasons for this richness in registered species is the variety of biomes and ecoregions in the state, which include the Cerrado, the Caatinga scrubland, and the Atlantic Forest (Galvão, 2014).

Chapada Diamantina is located in the center of Bahia State. This region has been the focus of many studies (Juncá et al., 2008; Funch et al., 2009) because it is considered a refuge for many species (Rodrigues-Filho et al., 2002). Sherlock and Serafim (1972) reported the presence of nine triatomine species in the Chapada Diamantina region: Panstrongylus diasi, P. geniculatus, P. lutzi, P. megistus, Triatoma bahiensis, T. maculata, T. melanocephala, T. sordida, and T. tibiamaculata. Forty years later, Souza et al. (2012) reported the occurrence of ten triatomine species in the Chapada Diamantina: P. diasi, P. geniculatus, P. lutzi, P. megistus, T. brasiliensis, T. infestans, T. melanocephala, T. lenti, T. pseudomaculata, and T. sordida. In other words, in the last forty years, only T. brasiliensis was newly reported in the Chapada Diamantina region. It is important to note that Sherlock and Serafim (1972) misidentified T. pseudomaculata as T. maculata, since T. maculata is a species restricted to the State of Roraima in Brazil (Galvão et al., 2003).

Some triatomine species are associated with bird nests (Lent and Wygodzinsky, 1979). Psammolestes tertius is one of the species with which triatomines have been associated. In most cases, these insects are found living in furnariid nests, particularly in those of the species Phacellodomus rufifrons Wied, 1821; P. ruber Vieillot, 1817 (Gurgel-Gonçalves and Cuba, 2011); and Anumbius annumbi Vieillot, 1817 (Turienzo and Di Iorio, 2008). Thus, in order to determine whether this species is present in the Chapada Diamantina region of Brazil, active searches of P. rufifrons nests were performed in the city of Seabra, Bahia State, Brazil $\left(12^{\circ} 32.449^{\prime} \mathrm{S}\right.$ and $\left.41^{\circ} 32.896^{\prime} \mathrm{W}\right)$, and $P$. tertius specimens were captured. 


\section{MATERIAL AND METHODS}

The triatomines were collected from the city of Seabra, Bahia (Figure 1), with help from the Central Laboratory for Public Health (LACEN-BA), and the Endemic Disease Control Center. On active searches of $P$. rufifrons nests made of thorny twigs, and hanging $1064 \mathrm{~m}$ high, 24 P. tertius specimens were collected, five of which were adult females, two of which were adult males, and 17 of which were nymphs. Beetles from the families Cerambycidae, Chrysomelidae, and Curculionidae were also identified around the nests, as were phytophagous hemipterans from the family Lygaeidae.

The P. tertius specimens were identified in the Parasitology Laboratory of the Department of Biological Science, School of Pharmaceutical Sciences at São Paulo State University, Araraquara (UNESP/FCFAR), São Paulo, Brazil. Identification was based on the criteria described previously by Lent and Wygodzinsky (1979). Feces from the specimens were examined. For this examination, the feces samples were diluted in saline solution and observed under a Leica MZ APO stereomicroscope. No Trypanosomatid forms were found. After identification, these insects were cytogenetically analyzed using lacto-aceto orcein techniques (De Vaio et al., 1985) with modifications according to Alevi et al. (2012), and also using C-banding (Sumner, 1972). The results were compared with those obtained by Panzera et al. (1998) who studied P. tertius from the Brazilian State of Ceará, in order to determine whether $P$. tertius exhibits any intraspecific chromosomal variation.

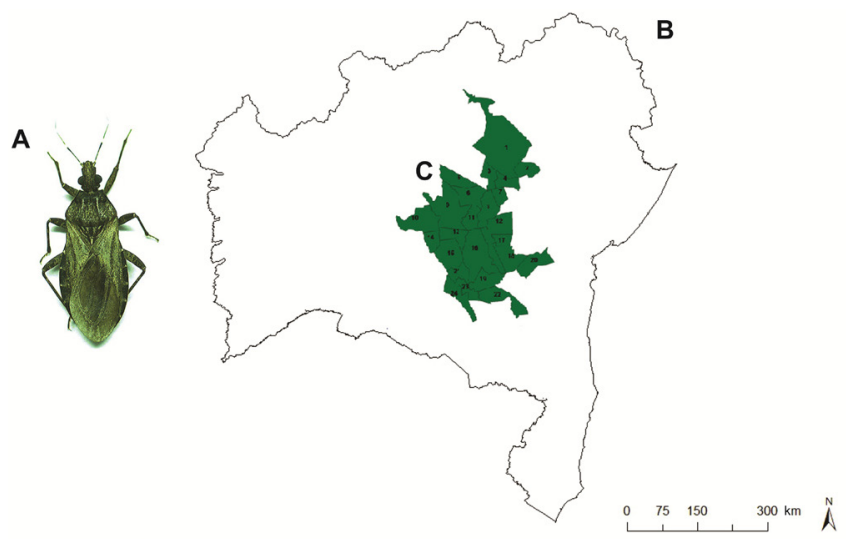

Figure 1. A. Psammolestes tertius male. B. Map of the Brazilian State of Bahia. C. Cities within the Chapada Diamantina region: 1 - Morro do Chapéu, 2 - Tapiramuta, 3 - Bonito, 4 - Utinga, 5 - Souto Soares, 6 - Iraquara, 7 - Wagner, 8 - Lençóis, 9 - Seabra, 10 - Ibitiara, 11 - Palmeira, 12 - Andarai, 13 - Boninal, 14 - Novo Horizonte, 15 Piatã, 16 - Mucugê, 17 - Nova Redenção, 18 - Itaetê, 19 - Ibicoara, 20 - Marcíonilio Souza, 21 - Abaira, 22 - Barra da Estiva, 23 - Jussiape, and 24 - Rio de Contas.

\section{RESULTS AND DISCUSSION}

The genus Psammolestes Bergroth, 1911, includes three species grouped into the Rhodniini tribe: P. arthuri (Pinto, 1926); P. coreodes Bergroth, 1911; and P. tertius Lent and Jurberg, 1965. P. arthuri distribution was found to be restricted to Colombia and Venezuela, while P. coreodes was reported in Argentina, Bolivia, Brazil, and Paraguay. P. tertius distribution is restricted to Brazil (Galvão, 2014). 
P. tertius is an exclusively sylvatic species that has not been associated with the transmission of Chagas disease, particularly because of its feeding habits, which are restricted to Chagas-resistant birds. Although the results were negative for infection by T. cruzi, this species has been found to be infected by protozoans (Lent and Wygodzinsky, 1979). The authors report that these flagellates were likely acquired from opossums found in abandoned bird nests that were still inhabited by triatomines.

The cytogenetic analyses performed on $P$. tertius revealed that this species does not present intraspecific chromosomal variation, since the specimens from Bahia presented the same characteristics described for the samples from Ceará (Panzera et al., 1998): 22 chromosomes (20 A + XY) (Figure 2A); little variation in autosome size (Figure 2A); Y chromosomes that were larger than the $\mathrm{X}$ chromosomes (Figure 2A), a chromocenter formed only by the $\mathrm{X}$ and $\mathrm{Y}$ chromosomes during initial prophase (Figure 2B; arrow); and autosomes lacking constitutive heterochromatin, which was restricted to the $\mathrm{Y}$ chromosomes (Figure 2C; arrow).

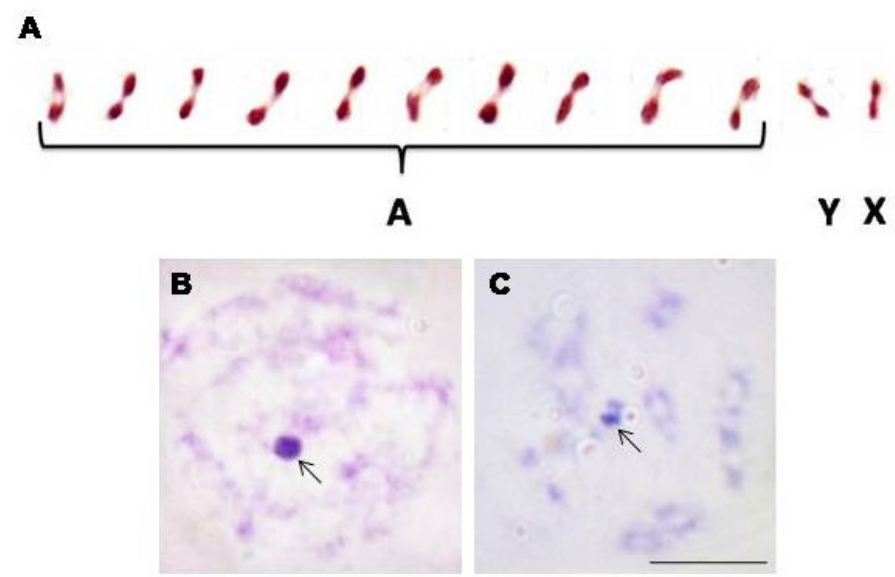

Figure 2. Karyotype (A) and constitutive heterochromatin disposition (B and C) in Psammolestes tertius. A. Metaphase I: Note that the species has 22 chromosomes, little variation in autosome size, and a Y chromosome that is larger than the $\mathrm{X}$ chromosome. B. Initial prophase. Note the heterochromatic chromocenter formed by the sex chromosomes (arrow). C. Final prophase. Note that only the Y chromosome is heterochromatic (arrow). Bar scale: $10 \mu \mathrm{m}$.

Intraspecific chromosomal variation in the Rhodniini tribe was observed in the case of $R$. ecuadoriensis (Pita et al., 2013) and R. pallescens (Gómez-Palacio et al., 2008). Both $P$. tertius and Rhodnius neglectus have been found to exhibit chromosomal homogeneity among specimens from different Brazilian states (Alevi et al., 2015b). Soares et al. (2001) analyzed two P. tertius populations by using morphometry, isoenzymes, and genetic analyses; they were able to distinguish between specimens from Ceará and specimens from the Brazilian State of Minas Gerais. These authors suggest that there is no gene flow between these populations, largely because they are geographically isolated. Although the results in our study did not reveal intraspecific variation, it is important to note that genetic evolution and chromosomal evolution are each guided by very different factors. The factors that cause variations in DNA sequences are more common than those that lead to chromosomal changes (Alevi et al., 2015c).

In conclusion, the presence of $P$. tertius in the Chapada Diamantina region of Brazil is described here for the first time, keeping in mind that this species presents intraspecific 
chromosomal homogeneity. Further studies are necessary to characterize this species. These studies will be particularly helpful in understanding this species in ecological, biological, biogeographical, and phylogenetic terms. In addition, studies are also necessary to determine triatomine fauna and their distribution in Brazil, particularly for species belonging to the genus Psammolestes.

\section{Conflicts of interest}

The authors declare no conflict of interest.

\section{ACKNOWLEDGMENTS}

Research supported by Fundação de Amparo à Pesquisa do Estado de São Paulo (FAPESP) (Process \#2013/19764-0) and Brazilian Federal Agency for the Support and Evaluation of Graduate Education (CAPES) grant process (\#23038.005285/20112012). Special acknowledgments are given to Aline Rimoldi Ribeiro for scientific assistance and Jucimar Vaz for help in the field.

\section{REFERENCES}

Alevi KCC, Mendonça PP, Pereira NP, Rosa JA, et al. (2012). Karyotype of Triatoma melanocephala Neiva and Pinto (1923). Does this species fit in the Brasiliensis subcomplex? Infect. Genet. Evol. 12: 1652-1653. http://dx.doi. org/10.1016/j.meegid.2012.06.011

Alevi KCC, Moreira FFF, Jurberg J and Azeredo-Oliveira MTV (2015a). Description of diploid chromosome set of Triatoma pintodiasi (Hemiptera, Triatominae). Genet. Mol. Res. 15: http://dx.doi.org/10.4238/gmr.15026343

Alevi KCC, Rodas LAC, Tartarotti E, Azeredo-Oliveira MTV, et al. (2015b). Entoepidemiology of Chagas disease in the Western region of the State of São Paulo from 2004 to 2008, and cytogenetic analysis in Rhodnius neglectus (Hemiptera, Triatominae). Genet. Mol. Res. 14: 5775-5784. http://dx.doi.org/10.4238/2015.May.29.9

Alevi KCC, Nunes GM, Rosa JA and Azeredo-Oliveira MTV (2015c). Homogeneidade cromossômica em diferentes populações de Panstrongylus megistus do Brasil. Rev. Ciênc. Farm. Básica e Aplic. 36: 307-310.

De Vaio ES, Grucci B, Castagnino AM, Franca ME, et al. (1985). Meiotic differences between three triatomine species (Hemiptera:Reduviidae). Genetica 67: 185-191. http://dx.doi.org/10.1007/BF02424489

Funch LS, Funch RR and Queiroz LP (2009). Serra do Sincorá, Parque nacional da Chapada Diamantina. Editora Radami, Feira de Santana, 251.

Galvão C (2014). Vetores da doença de chagas no Brasil. Sociedade Brasileira de Zoologia, Curitiba, Brasil, 289.

Galvão C, Carcavallo RU, Rocha DS and Jurberg J (2003). A checklist of the current valid species of the subfamily Triatominae Jeannel, 1919 (Hemiptera, Reduviidae) and their geographical distribution, with nomenclatural and taxonomic notes. Zootaxa 202: 1-36.

Gómez-Palacio A, Jaramillo-Ocampo N, Triana-Chávez O, Saldaña A, et al. (2008). Chromosome variability in the Chagas disease vector Rhodnius pallescens (Hemiptera, Reduviidae, Rhodniini). Mem. Inst. Oswaldo Cruz 103: 160-164. http://dx.doi.org/10.1590/S0074-02762008000200006

Gurgel-Gonçalves R and Cuba CAC (2011). Infestation of thornbird nests (Passeriformes: Furnariidae) by Psammolestes tertius (Hemiptera: Reduviidae) across Brazilian Cerrado and Caatinga ecoregions. Zoologia 28: 411-414. http:// dx.doi.org/10.1590/S1984-46702011000300017

Juncá FA, Funch L and Rocha W (2008). Biodiversidade e Conservação da Chapada Diamantina. Ministério do Meio Ambiente, Brasília, 435.

Lent H and Wygodzinsky P (1979). Revision of the Triatominae (Hemiptera: Reduviidae) and their significance as vector of Chagas's disease. Bull. Am. Mus. Nat. Hist. 163: 499-515.

Mendonça VJ, Alevi KCC, Pinotti H, Gurgel-Gonçalves R, et al. (2016). Revalidation of Triatoma bahiensis Sherlock \& Serafim, 1967 (Hemiptera; Reduviidae) and phylogeny of the T. brasiliensis species complex. Zootaxa 4107: 239-254.

Panzera F, Scvortzoff E, Pérez R, Panzera Y, et al. (1998). Cytogenetics of Triatomines. In: Atlas of Chagas disease vectors in the Americas (Carcavallo RU, Galíndez-Girón I, Jurberg J, Lent H, eds.). Editora Fiocruz, Rio de Janeiro, 621-664. 
Pita S, Panzera F, Ferrandis I, Galvão C, et al. (2013). Chromosomal divergence and evolutionary inferences in Rhodniini based on the chromosomal location of ribosomal genes. Mem. Inst. Oswaldo Cruz 108: 376-382. http://dx.doi. org $/ 10.1590 / \mathrm{S} 0074-02762013000300017$

Rodrigues-Filho S, Behling H, Irion G and Muller G (2002). Evidence for lake formation as a response to an inferred Holocene climatic transition in Brazil. Quat. Res. 57: 131-137. http://dx.doi.org/10.1006/qres.2001.2281

Sherlock IA and Serafim EM (1972). Fauna Triatominae do Estado da Bahia, Brasil. I. As espécies e distribuição geográfica. VI. Prevalência geográfica e infecção dos triatomíneos por Trypanosoma cruzi. Rev. Soc. Bras. Med. Trop. 6: 265-297.

Soares RP, Barbosa SE, Borges EC, Melo Júnior TA, et al. (2001). Genetic studies of Psammolestes tertius (hemiptera: reduviidae: triatominae) using male genital morphology, morphometry, isoenzymes, and random amplified polymorphic DNA. Biochem. Genet. 39: 1-13. http://dx.doi.org/10.1023/A:1002737601435

Souza NS, Oliveira KCS, Motta LRL, Costa Neto EM, et al. (2012). Distribuição geográfica de triatomíneos (Hemiptera, Reduviidae) e ação antrópica na região chapada Diamantina, Bahia. Anais do I ${ }^{o}$ Seminário Internacional de Ecologia Humana 1, 236-238.

Sumner AT (1972). A simple technique for demonstrating centromeric heterochromatin. Exp. Cell Res. 75: 304-306. http:// dx.doi.org/10.1016/0014-4827(72)90558-7

Turienzo P and Di Iorio O (2008). Insects found in birds' nests from Argentina: Anumbius annumbi (Vieillot, 1817) (Aves: Furnariidae). Zootaxa 1871: 1-55. 